\title{
Coping with Iron Deficiency and Iron Deficiency Anemia in Combat Recruits
}

\author{
Drorit Merkel $^{a}$ Daniel S. Moran ${ }^{b}$ \\ ${ }^{a}$ Division of Hematology, Chaim Sheba Medical Center, Tel Hashomer affiliated with Sackler School of Medicine, \\ Tel Aviv University, Tel Aviv, Israel; ${ }^{b}$ Ariel University, Ariel, Israel
}

Iron is a micronutrient necessary for energy metabolism and for oxygen transport and delivery. Depletion of iron stores (iron deficiency [ID]) may lead to ID anemia (IDA), which affects physical performance, mood, and cognitive function. Previous studies indicated that iron status may decline during military training in Israel and in other countries. Recently, Epstein et al. [1] found in strenuously training male army recruits after 6 months that the prevalence of anemia rose from 19 to $52 \%$ and that of ID from 33 to $35 \%$. During the 15-month followup, $29 \%$ of the recruits developed new IDA and $65 \%$ showed evidence of ID. The authors suggested that these findings can be partly explained by the physiological changes associated with strenuous physical activity. Merkel et al. [2] found ID of $15 \%$ in elite male units on recruitment, which increased to $27 \%$ after 6 months. In the US Army, ID of $32.8 \%$ was found among females immediately after basic training [3].

Physical training in combat units, and more emphasized in Special Forces, includes strenuous exercise causing stressed muscles and bones with commonly found overuse injuries. These injuries are associated with an inflammatory reaction with elevation of cytokine plasma

\section{KARGER}

() 2018 S. Karger AG, Basel

E-Mail karger@karger.com

www.karger.com/aha concentrations (e.g., interleukin [IL]-6, IL-1 receptor antagonist, and IL-10), C-reactive protein, and hepcidin [4].

Hepcidin is a regulator of iron metabolism and responsible for the entry of iron into the circulation. During inflammation, hepcidin values are increasing and iron regulation is affected. It appears that IL-6 elevation harms hepcidin regulation. Serum iron falls due to iron trapping within macrophages and liver cells and decreased gut iron absorption. This typically leads to anemia due to an inadequate amount of serum iron being available for developing red cells.

ID, with or without anemia, reduces physical performance, which is crucial in military environment and essential in combat units. Therefore, ID should be avoided. Commonly, ID and anemia are a result of a poor diet and of the growth spurt in adolescence. The gastrointestinal and the urinary tracts have also been implicated as sources of blood loss, especially after intense endurance training because of transient ischemia resulting from vasoconstriction of the splanchnic and renal vessels during exercise. In addition, "sport anemia," which has various contributing factors (i.e., dilution pseudo-anemia, intravascular mechanical hemolysis, and iron loss), is also a 
phenomenon reported in young males and females engaged in strenuous sport activities [5].

Because it was found that soldiers with normal hemoglobin levels performed better in the aerobic physical fitness test than those with anemia $[4,5]$, it is crucial to identify individuals with anemia and ID on the recruitment day to minimize the impact of army service on their physiological state. Military commanders could use this information to match soldiers to suitable training programs, thus possibly preventing overuse injuries. Thus, iron supplementation is recommended for ID or IDA soldiers [6].

\section{Recommendations}

(a) During military service of combat units, especially during basic and advanced training, follow-up for anemia, ID, and IDA is recommended and, accordingly, treatment of the soldiers with supplements.

(b) The combat soldiers should be provided with a quality diet that is rich in iron.

(c) Blood donation during strenuous training periods should be avoided.

\section{References}

$>1$ Epstein D, Borohovitz A, Merdler I, Furman M, Atalli E, Sorkin A, Stainfeld Y, Isenberg Y, Mashiach T, Shapira S, Weisshof R, Dann EJ: Prevalence of iron deficiency anemia in strenuously training male army recruits. Acta Haematol 2018;139:141-147.

2 Merkel D, Huerta M, Grotto I, Blum D, Rachmilewitz E, Fibach E, et al: Incidence of anemia and iron deficiency in strenuously trained adolescents: results of a longitudinal followup study. J Adolesc Health 2009;45:286-291.
>3 McClung JP, Marchitelli LJ, Friedl KE, Young AJ: Prevalence of iron deficiency and iron deficiency anemia among three populations of female military personnel in the US Army. J Am Coll Nutr 2006;25:64-69.

-4 Merkel D, Moran DS, Yanovich R, Evans RK, Finestone AS, Constantini N, Israeli E: The association between hematological and inflammatory factors and stress fractures among female military recruits. Med Sci Sports Exerc 2008;40(11 suppl):S691-S697.
5 Novack V, Finestone AS, Constantini N, Shpilberg O, Weitzman S, Merkel D: The prevalence of low hemoglobin values among new infantry recruits and nonlinear relationship between hemoglobin concentration and physical fitness. Am J Hematol 2007;82:128133

6 Burden RJ, Morton K, Richards T, Whyte GP, Pedlar CR: Is iron treatment beneficial in iron-deficient but non-anemic (IDNA) endurance athletes? A systematic review and meta-analysis. Br J Sports Med 2015;49:13891397. 